\title{
Does the Microbiome Affect the Outcome of Renal Transplantation?
}

\author{
Paul M. Campbell ${ }^{1 *}$, Gavin J. Humphreys ${ }^{1}$, Angela M. Summers ${ }^{2}$, Joanne E. Konkel ${ }^{3}$, \\ Christopher G. Knight ${ }^{4}$, Titus Augustine ${ }^{2}$ and Andrew J. McBain ${ }^{1}$ \\ ${ }^{1}$ School of Health Sciences, Faculty of Biology, Medicine and Health, The University of Manchester, Manchester, \\ United Kingdom, ${ }^{2}$ Department of Renal and Pancreatic Transplantation, Manchester University NHS Foundation Trust, \\ Manchester Academic Health Science Centre, Manchester, United Kingdom, ${ }^{3}$ Lydia Becker Institute of Immunology \\ and Inflammation, Faculty of Biology, Medicine and Health, The University of Manchester, Manchester, United Kingdom, \\ ${ }^{4}$ School of Natural Sciences, Faculty of Science and Engineering, The University of Manchester, Manchester, \\ United Kingdom
}

OPEN ACCESS

Edited by:

Kathryn Whitehead, Manchester Metropolitan University, United Kingdom

Reviewed by:

Anthony Joseph Slate, University of Bath, United Kingdom

Niels Olsen Saraiva Camara,

University of São Paulo, Brazil

*Correspondence:

Paul M. Campbell paul.campbell-5@manchester.ac.uk

Specialty section:

This article was submitted to Microbiome in Health and Disease,

a section of the journal

Frontiers in Cellular

and Infection Microbiology

Received: 03 May 2020 Accepted: 17 November 2020 Published: 23 December 2020

Citation:

Campbell PM, Humphreys GJ, Summers AM, Konkel JE, Knight CG,

Augustine T and McBain AJ (2020)

Does the Microbiome Affect the

Outcome of Renal Transplantation?

Front. Cell. Infect. Microbiol. 10:558644.

doi: 10.3389/fcimb.2020.558644
The role of the human microbiome in health and disease is becoming increasingly apparent. Emerging evidence suggests that the microbiome is affected by solid organ transplantation. Kidney transplantation is the gold standard treatment for End-Stage Renal Disease (ESRD), the advanced stage of Chronic Kidney Disease (CKD). The question of how ESRD and transplantation affect the microbiome and vice versa includes how the microbiome is affected by increased concentrations of toxins such as urea and creatinine (which are elevated in ESRD), whether restoration of renal function following transplantation alters the composition of the microbiome, and the impact of lifelong administration of immunosuppressive drugs on the microbiome. Changes in microbiome composition and activity have been reported in ESRD and in therapeutic immunosuppression, but the effect on the outcome of transplantation is not wellunderstood. Here, we consider the current evidence that changes in kidney function and immunosuppression following transplantation influence the oral, gut, and urinary microbiomes in kidney transplant patients. The potential for changes in these microbiomes to lead to disease, systemic inflammation, or rejection of the organ itself is discussed, along with the possibility that restoration of kidney function might re-establish orthobiosis.

Keywords: oral microbiome, gut microbiome, kidney transplant, surgery, renal allograft, urinary microbiome, chronic kidney disease, end stage renal disease

\section{INTRODUCTION}

The human microbiome can confer multiple benefits to health (Wang et al., 2017). Examples include aiding development of organs (Goyal et al., 2015) and the innate and adaptive immune systems (Lee and Mazmanian, 2010; Honda and Littman, 2016; Thaiss et al., 2016) and resistance to infection (Bäumler and Sperandio, 2016).

The immune system controls the human microbiome, for example, in the small intestine, where the antimicrobial peptide RegIII $\gamma$ restricts the number of bacteria in contact with the epithelial surface, and secreted innate immune effectors can alter the composition of luminal microbiota (Vaishnava et al., 2011; Hooper et al., 2012). Current evidence suggests that the microbiome differs in diseases where immune function is altered (Belkaid and Hand, 2014; Idris et al., 2017), including: 
hematological malignancies (Bergmann, 1989; Galili et al., 1992; Wang et al., 2014), pro-inflammatory cancers (Pushalkar et al., 2011; Farrell et al., 2012; Han et al., 2014; Hu et al., 2015; Fan et al., 2018) and inflammatory bowel diseases (Docktor et al., 2012). The effects of microbiome change on patient outcomes have, however, not been fully elucidated. Organ transplantation and subsequent immunosuppression offer the opportunity to study the effects of immunosuppression longitudinally.

Despite advances in treatment, data yielded by the ELITESymphony trial reported that infections and rejection, broadly associated with over-immunosuppression and underimmunosuppression respectively, occurred in approximately $25 \%$ of cases within one year of renal transplantation (Cippà et al., 2015). A knowledge gap remains regarding optimal immunosuppression, which may be considered to be a balance of risk between the two outcomes. Understanding the processes driving microbiome change and potential downstream consequences to health could therefore inform prediction, prevention, and management of post-transplant outcomes. This review considers evidence that microbiome composition is linked to outcome in kidney transplant surgery. We additionally consider how changes in kidney function can affect both the immune system and the microbiome, and the evidence that microbiome alteration could lead to acute rejection.

\section{USE OF IMMUNOSUPPRESSANTS IN TRANSPLANTATION}

Advancements in immunosuppressant therapies have led to improvements in the success of kidney transplantation. Ciclosporin and tacrolimus have been used in this application since the 1980s (Spencer et al., 1997; Spolidorio et al., 2006; Colombo and Ammirati, 2011). Both calcineurin-inhibiting drugs interact with intracellular proteins of the immunophilin family; the former forms a complex with cyclophilin, and the latter with FK506-binding protein 12 with greater molar potency (Halloran, 2004). Since $90 \%$ of kidney transplant recipients in the US received a calcineurin inhibitor-based regime in 2012 (Matas et al., 2014), the majority of microbiome studies in this area are based on patient cohorts following ciclosporin or tacrolimusbased regimes. However, modern kidney transplantation procedures involve several other immunosuppressive agents, including prednisone, mycophenolate mofetil, sirolimus, and azathioprine, with or without added steroids (Diaz et al., 2013).

Immunosuppressant drugs, including tacrolimus, can function as a macrolide antibiotic and such properties are likely to affect bacteria. Moreover, prophylactic antibiotics may also significantly alter the microbiome (Jakobsson et al., 2010; Korpela et al., 2016), confounding investigations into the effect of immunosuppression. Comparisons between cohorts may be complicated by the lack of consensus on optimal perioperative prophylaxis regimes (Orlando et al., 2015; Bliven et al., 2018), but such confounders may be avoided by using living organ donors as controls paired with their recipients. However, the effect of factors which solely affect chronic kidney disease patients pretransplant (specialized diet, uremic toxins) are less easily disentangled from immunosuppression.

\section{THE ORAL MICROBIOME DURING IMMUNOSUPPRESSION}

There is a longstanding association between immunosuppressive agents and oral disease. Gingival hyperplasia, for example, has been associated with the immunosuppressant ciclosporin, and kidney-transplantation (Rateitschak-Plüss et al., 1983) where bacteria-induced inflammation could be affected by transplantdriven microbiome changes (Brown et al., 1991). In a large study of kidney transplant patients, $60 \%$ had at least one type of oral mucosal ulcer (de la Rosa-García et al., 2005). Similar studies indicate that these lesions are common in transplant or immunocompromised cohorts with causal links to oral microbiome constituents. Oral candidiasis is also more common in transplant recipients and immunosuppressed cohorts (King et al., 1994; Olczak-Kowalczyk et al., 2010). Whether the overgrowth and increased prevalence of Candida spp. in this context is caused by failure of the immunocompromised host to maintain normal suppression of its growth, or a side effect of prophylactic antibiotic use (Lynch, 1994), remains to be discerned.

Immunosuppression has been reported to alter the composition of the oral microbiome beyond six months posttransplant (Diaz et al., 2013; Fricke et al., 2014). A study comparing subgingival plaque bacteria reported increased bacterial counts and clinical indicators of gingival overgrowth post-transplantation (Saraiva et al., 2006). More recently, significant and persistent differences have been reported in kidney transplant recipients before and after transplant (Table 1). The potential for these changes to negatively impact patient health is suggested by increases in opportunistic pathogens, which has been reported even where concurrent differences in alpha-diversity and global community structure are not observed (Diaz et al., 2013).

\section{THE CONTRIBUTION OF CHANGES IN THE ORAL MICROBIOME TO TRANSPLANT-ASSOCIATED DISEASE}

Increased prevalence of opportunistic pathogens in the oral microbiome of transplant patients including Enterobacteriaceae, Pseudomonas fluorescens, Actinetobacter spp., and Vibrio spp., have been reported (Diaz et al., 2013). Some of the same taxa incur greater relative abundance in critically ill patients $(\mathrm{McD}$ onald et al., 2016). Post-transplant infections remain the leading cause of morbidity and mortality in kidney transplantation, occurring in $31 \%$ of recipients within the first two years (Karuthu and Blumberg, 2012; Cowan et al., 2018). The source of infections within around one month of transplantation may be hositialacquired whereas those in the subsequent five months may be due 
TABLE 1 | Summary of recent studies reporting microbiome-associated differences (and their, potentially, related, post-operative effects) using kidney transplant recipient (KTR) cohorts.

\begin{tabular}{|c|c|c|c|c|c|c|}
\hline Study & $\begin{array}{l}\text { Microbiome } \\
\text { Site }\end{array}$ & $\begin{array}{l}\text { Immunosuppressive } \\
\text { Agents Administered }\end{array}$ & Comparison & Microbiome Change Reported & $\begin{array}{c}\text { Post-Operative Outcome } \\
\text { Reported }\end{array}$ & Method of Detection \\
\hline $\begin{array}{l}\text { (Diaz } \\
\text { et al., } \\
\text { 2013) }\end{array}$ & Oral & $\begin{array}{l}\text { Prednisone, } \\
\text { Mycophenolate } \\
\text { mofetil, Tacrolimus, } \\
\text { Ciclosporin, Sirolimus, } \\
\text { Azathioprine }\end{array}$ & $\begin{array}{l}\text { Kidney and } \\
\text { Cardiac Transplant } \\
\text { Recipients (20) vs } \\
\text { healthy cohort (19) }\end{array}$ & $\begin{array}{l}\text { Increased prevalence of potentially } \\
\text { opportunistic pathogens } \\
\text { (K. pneumoniae, P. fluorescens, } \\
\text { Acinetobacter spp, Vibrio spp., } \\
\text { Enterobacteriaceae spp.) }\end{array}$ & $\begin{array}{l}\text { Cluster of opportunistic } \\
\text { pathogens correlated with } \\
\text { serum C-reactive protein, } \\
\text { potential link between flora } \\
\text { and systemic inflammation }\end{array}$ & 16S rRNA sequencing \\
\hline $\begin{array}{l}\text { (Saraiva } \\
\text { et al., } \\
\text { 2006) }\end{array}$ & Oral & Ciclosporin & $\begin{array}{l}35 \mathrm{KTRs} \text { before } \\
\text { and after } \\
\text { procedure }\end{array}$ & $\begin{array}{l}\text { Increase in total viable counts of } \\
\text { microorganisms on day } 90 \text { after } \\
\text { surgery }\end{array}$ & $\begin{array}{l}\text { Increased gingival } \\
\text { overgrowth } \\
\text { Beta-hemolytic } \\
\text { Streptococcus detected } \\
\text { less frequently in gingival } \\
\text { overgrowth }\end{array}$ & $\begin{array}{l}\text { Culturing and oral } \\
\text { disease diagnoses }\end{array}$ \\
\hline $\begin{array}{l}\text { (Spolidorio } \\
\text { et al., } \\
\text { 2006) }\end{array}$ & Oral & $\begin{array}{l}\text { Ciclosporin and } \\
\text { Tacrolimus }\end{array}$ & $\begin{array}{l}\text { KTRs receiving } \\
\text { ciclosporin (88) } \\
\text { and tacrolimus (67) }\end{array}$ & $\begin{array}{l}\text { Increased levels of Candida spp. } \\
\text { detected in ciclosporin group }\end{array}$ & $\begin{array}{l}\text { Increased gingival } \\
\text { overgrowth, candida } \\
\text { infection, squamous cell } \\
\text { carcinoma and herpes } \\
\text { simplex in ciclosporin } \\
\text { group }\end{array}$ & $\begin{array}{l}\text { Culturing and oral } \\
\text { disease diagnoses }\end{array}$ \\
\hline $\begin{array}{l}\text { (Swarte } \\
\text { et al., } \\
\text { 2020) }\end{array}$ & Gut & $\begin{array}{l}\text { Ciclosporin, } \\
\text { tacrolimus, } \\
\text { azathioprine, } \\
\text { mycophenolate } \\
\text { mofetil, prednisolone }\end{array}$ & $\begin{array}{l}\text { KTRs after } \\
\text { procedure (139) } \\
\text { and healthy } \\
\text { controls (105). }\end{array}$ & $\begin{array}{l}\text { Lower Shannon diversity detected in } \\
\text { KTR group. } \\
\text { Use of mycophenolate mofetil } \\
\text { correlated with lower diversity }\end{array}$ & na & 16S rRNA sequencing \\
\hline $\begin{array}{l}\text { (Lee et al., } \\
\text { 2019) }\end{array}$ & Gut & $\begin{array}{l}\text { Anti-thymocyte } \\
\text { globulin, basiliximab, } \\
\text { tacrolimus, belatacept, } \\
\text { mycophenolate } \\
\text { mofetil, prednisone }\end{array}$ & $\begin{array}{l}71 \text { KTRs (Diarrheal } \\
\text { specimens vs non- } \\
\text { diarrheal) }\end{array}$ & $\begin{array}{l}\text { Lower Shannon diversity in diarrheal } \\
\text { specimens. } \\
\text { Lower relative abundance of } 13 \text { genera } \\
\text { in diarrheal fecal specimens vs non- } \\
\text { diarrheal }\end{array}$ & $\begin{array}{l}26 \text { out of } 28 \text { diarrheal } \\
\text { specimens negative for } \\
\text { infectious etiologies. } \\
\text { Diarrhea specimens } \\
\text { predicted to have lower } \\
\text { abundance of metabolic } \\
\text { genes }\end{array}$ & $\begin{array}{l}\text { 16S rRNA sequencing } \\
\text { and PICRUSt (Langille } \\
\text { et al., 2013) }\end{array}$ \\
\hline $\begin{array}{l}\text { (Zaza } \\
\text { et al., } \\
2017)\end{array}$ & Gut & $\begin{array}{l}\text { Everolimus, tacrolimus, } \\
\text { mycophenolate mofetil }\end{array}$ & $\begin{array}{l}9 \text { KTRs receiving } \\
\text { everolimus and } 11 \\
\text { KTRs receiving } \\
\text { tacrolimus }\end{array}$ & $\begin{array}{l}\text { Alpha diversity not significantly different } \\
\text { Three functional genes (fliNY, pilM and } \\
\text { msrA) discriminated microbiome profile } \\
\text { of each group }\end{array}$ & na & $\begin{array}{l}\text { Taxonomic profiling } \\
\text { via } 16 \text { S rRNA } \\
\text { sequencing \& } \\
\text { functional analysis } \\
\text { using DIAMOND } \\
\text { (Buchfink et al., 2015) }\end{array}$ \\
\hline $\begin{array}{l}\text { (Lee et al., } \\
\text { 2014) }\end{array}$ & Gut & $\begin{array}{l}\text { Tacrolimus and } \\
\text { Mycophenolate acid or } \\
\text { Mycophenolate mofetil }\end{array}$ & $\begin{array}{l}26 \text { KTRs before } \\
\text { and after } \\
\text { procedure }\end{array}$ & $\begin{array}{l}\text { Increase in relative abundance of } \\
\text { Proteobacteria post-transplant }\end{array}$ & $\begin{array}{l}\text { Post-transplant diarrhea } \\
\text { associated with lower } \\
\text { Shannon diversity index } \\
\text { PCoA }^{1} \text { and LEfSe } \\
\text { distinguish between acute } \\
\text { rejection and no acute } \\
\text { rejection group } \\
\text { Fecal abundance of } \\
\text { Enterococcus associated } \\
\text { with urinary tract infection }\end{array}$ & 16S rRNA sequencing \\
\hline $\begin{array}{l}\text { (Wu et al., } \\
\text { 2018) }\end{array}$ & Urinary & $\begin{array}{l}\text { Tacrolimus, } \\
\text { Ciclosporin and none. }\end{array}$ & $\begin{array}{l}35 \text { KTRs with } \\
\text { Chronic Allograft } \\
\text { Dysfunction vs } 32 \\
\text { KTRs without }\end{array}$ & $\begin{array}{l}\text { Shannon diversity index and beta } \\
\text { diversity not significantly different } \\
\text { between groups. } \\
21 \text { OTUs }^{3} \text { significantly higher in } \\
\text { Chronic Allograft Dysfunction cases }\end{array}$ & na & 16S rRNA sequencing \\
\hline $\begin{array}{l}\text { (Modena } \\
\text { et al., } \\
2017 \text { ) }\end{array}$ & Urinary & $\begin{array}{l}\text { Tacrolimus, } \\
\text { Mycophenolate mofetil } \\
\text { and Prednisone }\end{array}$ & $\begin{array}{l}25 \text { KTRs } \\
\text { developing IFTA vs } \\
23 \text { KTRs with } \\
\text { normal biopsies } \\
\text { and } 20 \text { non- } \\
\text { transplant controls }\end{array}$ & $\begin{array}{l}\text { Streptococcus lower in IFTA }{ }^{4} \text { and } \\
\text { "normal" KTR males vs healthy male } \\
\text { controls (after } 1 \text { month). Further } \\
\text { decreased after 6-8 months in IFTA } \\
\text { males, but normalized in "normal" KTR } \\
\text { males } \\
\text { IFTA associated with a loss in } \\
\text { dominant resident urinary microbes in } \\
\text { males, and parallel increase in } \\
\text { nonresident, pathogenic bacteria in } \\
\text { males and females }\end{array}$ & na & 16S rRNA sequencing \\
\hline
\end{tabular}


TABLE 1 | Continued

\begin{tabular}{|c|c|c|c|c|c|c|}
\hline Study & $\begin{array}{l}\text { Microbiome } \\
\text { Site }\end{array}$ & $\begin{array}{l}\text { Immunosuppressive } \\
\text { Agents Administered }\end{array}$ & Comparison & Microbiome Change Reported & $\begin{array}{c}\text { Post-Operative Outcome } \\
\text { Reported }\end{array}$ & Method of Detection \\
\hline $\begin{array}{l}\text { (Fricke } \\
\text { et al., } \\
\text { 2014) }\end{array}$ & $\begin{array}{l}\text { Blood, } \\
\text { Urinary, Oral } \\
\text { and Rectal }\end{array}$ & Not Reported & $\begin{array}{l}60 \text { KTRs before } \\
\text { and after } \\
\text { procedure }\end{array}$ & $\begin{array}{l}\text { Differences in structure observed } \\
\text { between pre- and } 1 \text { month post- } \\
\text { transplant (persisted after } 6 \text { months) } \\
\text { Decreases in Proteobacteria } \\
\text { Escherichia, Porphyromonas (urine) } \\
\text { and Haemophilus, Neisseria, } \\
\text { Pasteurella (oral) }\end{array}$ & $\begin{array}{l}\text { Pre-transplant microbiota } \\
\text { associated with } \\
\text { subsequent rejection and } \\
\text { infection events }\end{array}$ & $16 \mathrm{~S}$ rRNA sequencing \\
\hline
\end{tabular}

${ }^{1}$ Principal coordinates analysis.

${ }^{2}$ Linear discriminant analysis effect size.

${ }^{3}$ Operational taxonomic units.

${ }^{4}$ Interstitial fibrosis and tubular atrophy.

na, not applicable.

to opportunistic pathogens beginning to take advantage of immunosuppression (Karuthu and Blumberg, 2012). Oral microbiome analysis indicates that some taxa increasing in abundance following transplantation are those associated with common post-transplant infections; particularly Klebsiella pneumoniae and Pseudomonas spp. (Hlava et al., 2009; Diaz et al., 2013). Indeed, extra-oral colonization by opportunistic oral microbiota has been associated with a large number of diseases (Han and Wang, 2013), representing a significant risk to immunocompromised patients after transplantation.

Oral cancers are frequently observed in kidney transplant recipients (Regev et al., 1992; Thomas et al., 1993; Seymour et al., 1997; Yoon et al., 2003; Spolidorio et al., 2006; Campistol and Schena, 2007). Patients undergoing immunosuppression are generally more susceptible to some systemic cancers (Gardner et al., 2004; Sinha et al., 2004; Gutierrez-Dalmau and Campistol, 2007), but whether such higher rates of oral cancer are linked to altered microbial activity, such as through increased inflammation, or unconnected side-effects of the immunosuppression itself, is unclear. It has been proposed that colonization of dysplastic oral tissue by Candida spp. might accelerate progression towards oral squamous cell carcinoma. Elsewhere, microbe-driven inflammation by Helicobacter pylori and Fusobacterium nucleatum have been linked to carcinogenesis (Chiba et al., 2008; Castellarin et al., 2012; Kostic et al., 2012). Alongside direct action on epithelial cells, H. pylori indirectly drives carcinogenesis through the secretion of virulence factors (e.g. $\gamma$-Glutamyl transpeptidase) causing oxidative stress and longterm inflammation (Díaz et al., 2018). Similarly, in the oral cavity, carcinoma could involve secondary metabolite-driven inflammation, the production of genotoxic substances such as acetaldehyde, or cell invasion (Healy and Moran, 2019).

\section{PRE-TRANSPLANT, CO-MORBIDITIES EXACERBATE SYSTEMIC INFLAMMATION}

Evidence for the interaction between chronic kidney disease (CKD) and chronic periodontitis (CP) has been reviewed by
Hickey et al. (2020). Certain bacteria are understood to cause local kidney damage, e.g. acute post-streptococcal glomerulonephritis, a common nephric condition often attributed to group A streptococci (Ahn and Ingulli, 2008). Systemic interplay between chronic periodontitis and chronic kidney disease may however go beyond this to exacerbate both conditions, with CKD-associated $\mathrm{pH}$ changes and gingival hyperplasia creating favorable conditions for the growth of oral pathogens (Listgarten, 1986), and $\mathrm{CP}$-associated systemic inflammation aggravating that already associated with CKD (Paraskevas et al., 2008; Wahid et al., 2013).

\section{SALIVARY UREA IN KIDNEY DISEASE AND TRANSPLANTATION}

$\mathrm{CKD}$ causes the accumulation of waste products, including urea, to concentrate in the blood and saliva (Pandya et al., 2016). As a consequence, salivary urea concentration may be up to four times higher in CKD patients than healthy individuals (Lasisi et al., 2016). Oral bacteria including Streptococcus salivarius can metabolize urea to carbonic acid and ammonia, with a net increase in pH (Casiano-Colón and Marquis, 1988; Wijeyeweera and Kleinberg, 1989; Chen et al., 1996; MorouBermudez and Burne, 1999; Yaling et al., 2006; Nascimento et al., 2009) which may differentially affect the growth of oral bacteria with higher pH optima (Bowden and Hamilton, 1987; Quivey et al., 2000; Marsh and Devine, 2011; Ratzke and Gore, 2018), possibly contributing to differences seen in the microbiome of CKD patients versus healthy controls ( $\mathrm{Hu}$ et al., 2018). Alkalization has been suggested to have a role in protection against acidification and demineralization of enamel (Kleinberg et al., 1982; Burne and Marquis, 2000) which may influence the lower caries incidence reported in CKD patients (Peterson et al., 1985; Al Nowaiser et al., 2003; Andrade et al., 2013). Moreover, shifts in oral pH could affect the immune system (Lardner, 2001; Erra Díaz et al., 2018).

Diseases that increase urea concentrations have also been linked to various oral co-morbidities, chronic renal failure 
patients may have increased dental plaque, enamel defects, and gingival enlargement compared with healthy individuals (Al Nowaiser et al., 2003). Since the objective of kidney transplantation is to restore kidney function, which normalizes urea concentrations, a better understanding of downstream consequences on the oral microbiome may inform dental care post-transplant. It is unclear whether the restoration of kidney function causes the oral microbiome to return to original function and composition and how this affects the risk of future oral disease. Also relevant would be the effect of resulting ammonia concentration change on ammoniaoxidizing archaea (Pester et al., 2011). Oral archaea, including those capable of oxidizing ammonia, have been associated with periodontal disease (Lepp et al., 2004; de Macario and Macario, 2009; Probst et al., 2013) although many studies focus solely on eubacteria.

\section{THE GUT MICROBIOME IS STRUCTURALLY ALTERED BY IMMUNOSUPPRESSANTS}

The large intestine is the most heavily colonized site in the body where microbial cell density exceeds all other human microbiome sites by at least two orders of magnitude (Sender et al., 2016). The gut microbiome has a profound influence on host metabolism and immunity (Sekirov et al., 2010), and its composition remains relatively stable in healthy adults (Huttenhower et al., 2012). Following transplantation, however, significant changes to structure have been reported (Table 1).

In solid organ transplantation, the immunosuppressants ciclosporin and tacrolimus have been well documented to result in significant structural changes to the gut microbiome. A large liver transplantation study reported that recipients, largely administered with ciclosporin or tacrolimus (plus mycophenalite mofetil), had decreased Bifidobacterium spp., Lactobacillus spp. and Faecalibacterum prausnitzii, and significantly higher Enterobacteriaceae and Enterococcus spp. ( Wu et al., 2012). Although gut microbiomes are individualized (Dethlefsen et al., 2007) key compositional changes including lower overall diversity (Swarte et al., 2020) and increases in the relative abundance of Proteobacteria (Lee et al., 2014) have been reported post-transplantation. Whether fecal microbiota transplantation could restore the microbiome post-transplant, an effective treatment for Clostridium difficile infection, remains to be studied at scale (Al Khodor and Shatat, 2017).

There is some evidence that manipulating the immune response via changes in the gut microbiome could be used to modify allograft outcomes. This has been investigated in murine models, where treatment using gut microbiota has significantly improved skin allograft survival via tolerogenic immune responses (Zhang et al., 2018). Moreover, manipulating the growth of species such as Faecalibacterium prausnitzii which are capable of metabolizing the immunosuppressant tacrolimus might reduce the requirement to increase immunosuppressant dose later in treatment (Lee et al., 2015; Guo et al., 2019). This could reduce the prevalence and severity of side effects caused by an increased dose. Ultimately both examples highlight the high motivation for, and utility of, understanding how microbiome change could manipulate transplant outcome.

\section{KEY STRUCTURAL AND FUNCTIONAL CHANGES IN THE GUT COULD CAUSE REJECTION}

Immunosuppressants can affect the microbiome in complex and co-occurring ways. For example, the gut microbiome of patients treated with everolimus in combination with mycophenolate mofetil had similar alpha diversity to those treated with tacrolimus in combination with mycophenolate mofetil (Zaza et al., 2017). By going beyond comparisons of solely taxonomic composition, the same study reported that the relative abundance of three functional genes could distinguish between these groups. Metabolic pathways usually remain stable within healthy populations (Huttenhower et al., 2012). Here, flagellar motor switch protein (fliNY) and type IV pilus assembly protein pilM (pilM) genes were found to be enriched in tacrolimustreated patients, whereas macrolide transport system msrA (msrA) was more abundant in the everolimus group.

Fecal samples from kidney transplant patients with posttransplant diarrhea had lower microbial diversity and abundance of 13 commensal genera (Lee et al., 2019). Whereas patients without diarrhea had significantly lower relative abundances of 3 genera: Enterococcus, Escherichia, and Lachnoclostridium. Significant differences were also reported in several metabolic pathways in diarrheal groups, including decreases in metabolic pathways involved in sucrose, starch, and amino acid metabolism. The most significant change was a reduction in cellobiose phosphorylase, a gene involved in cellobiose metabolism shown to induce diarrhea in rats (Moinuddin and Lee, 1958). In an attempt to moderate post-transplant diarrhea, practitioners regularly reduce dosages of the immunosuppressant mycophenolate mofetil, despite the increased risk of graft failure (Bunnapradist et al., 2006). By investigating how immunosuppression leads to differences in microbiome function, novel targets for prevention or treatment of posttransplant diarrhea might remove the requirement for reduction of the immunosuppressant dose.

There is emerging evidence for an association between transplantation-linked microbiome change and acute rejection of the organ. Disparity in the microbiome profiles of patients following non-rejection or acute rejection of transplanted organs has been observed in small bowel transplantation (Oh et al., 2012), and similar findings have been reported in a pilot study following kidney transplantation (Lee et al., 2014). Whether changes in the microbiome precede or follow acute rejection remains to be shown. Should they follow or non-causally precede 
acute rejection, microbial signifiers of rejection could provide a potential biomarker for early diagnosis (Fricke et al., 2014; Ren et al., 2014). If these changes precede acute rejection due to causality, they may instead provide a modifiable target for prevention. The composition of the microbiota, and the metabolites produced, can promote both inflammatory and tolerogenic immune responses towards transplanted organs (Ardalan and Vahed, 2017). Short-chain fatty acids produced by intestinal microbiota may provide protection against local and systemic inflammation, oxidative cellular stress, cell infiltration/activation, and apoptosis, as in murine models of acute kidney injury (Andrade-Oliveira et al., 2015). Identifying features causing such responses could, therefore, initiate the development of pre- or pro- biotic therapies aiming to improve long-term allograft outcome (Ardalan and Vahed, 2017).

\section{COULD DELAYED KIDNEY FUNCTION LEADING TO GUT DYSFUNCTION FAVOR REJECTION?}

The structure of the gut microbiome is known to be altered in individuals with kidney disease (Al Khodor and Shatat, 2017; Nallu et al., 2017). Investigations in humans and rat models have shown differences between the gut microbiome in uremic subjects with ESRD and healthy controls (Vaziri et al., 2013a). The effect of renal transplantation has, however, not been extensively investigated. Renal dysfunction with increased serum urea leads to intestinal barrier dysfunction and disruption of the epithelial tight junction (Vaziri et al., 2013b). Such disruptions allow bacterial fragments and toxins to translocate from the gut microbiome into the bloodstream, promoting chronic systemic inflammation (Vaziri et al., 2012); whether this has a causal or exacerbating affect in co-morbidities associated with ESRD is unclear. After transplantation, there is some degree in variability as to how quickly the kidney allograft begins to function, although in recent years the incidence of delayed graft function has increased, possibly due to the use of expanded donor criteria, to within the range of $20-45 \%$ of cases (Yarlagadda et al., 2009; Matas et al., 2014; Willicombe et al., 2017; Jansen et al., 2018). Delayed graft function may expose the patient to a longer period of uremia and an increased risk of gut dysfunction, systemic inflammation, and allograft rejection. A delayed graft function of more than six days has been found to strongly decrease the long-term survival of transplanted kidneys (Giral-Classe et al., 1998).

\section{URINARY MICROBIOME MAY HOLD KEY TO EARLY REJECTION DETECTION}

Since the recognition of its medical relevance, the urinary microbiome has been receiving growing attention
(Fouts et al., 2012; Wolfe et al., 2012; Aragon et al., 2018). The most frequently reported genera are Lactobacillus and Streptococcus, with Alloscardovia, Burkholderia, Jonquetella, Klebsiella, Saccharofermentans, Rhodanobacter, and Veillonella also found less frequently (Aragon et al., 2018). Whilst the importance of the urinary microbiome in health is still emerging, evidence from several studies confirm its composition is altered by some post-transplant situations (Table 1). A study comparing the urinary microbiome of 21 kidney transplant recipients with that of 8 healthy controls reported marked differences between the two groups (Rani et al., 2017). Under the multiple stressors of kidney transplantation (including antibiotics, immunosuppression, and environmental changes) the urinary microbiota of kidney-transplant recipients suggested an overall decrease in diversity when compared to healthy controls, alongside an increased abundance of opportunistic pathogens (Escherichia coli and Enterococcus faecalis) and may select for promotion of antibiotic resistance. The effect of elevated urinary urea concentrations on urinary tract infections caused by urealytic pathogens also warrants further investigation. In the future, frequent, longitudinal sampling of the patient's urinary microbiome might be implemented to detect deviations from microbiome stability. If these changes are shown to precede organ damage or loss, this may be useful as a non-invasive method of early detection.

\section{CONCLUSION AND PERSPECTIVES}

Alterations in the composition and activities of the human microbiome can have a range of consequences. Microbiome changes due to reduced kidney function in CKD and ESRD may be exacerbated during transplantation, with associated immunosuppression and restoration of kidney function. Whilst progress has been made in defining associations between the microbiome and kidney transplantation (summarized in Figure 1), the causal links and health consequences of these associations are not completely understood. Whilst few studies have investigated changes over prolonged timeframes in prospective cohorts, some pioneering studies have proposed how the microbiome alteration might translate to functional changes and alter post-transplant outcomes. An important goal of future research will be to tackle the challenges that kidney transplantation still faces. Indeed, evidence presented here implies a role for microbiome research in earlier detection and prevention of post-transplant infection and acute rejection, and achieving optimum individualized immunosuppression regimes to alleviate side effects. By increased understanding of how the microbiome and the immune system are affected by transplantation, clinically relevant information may be provided to enable treatment optimization for renal transplant recipients. To do so, large scale observations of kidney transplant recipients and donors are recommended to model the effects of co-occurring factors such as urea change, immunosuppression, 


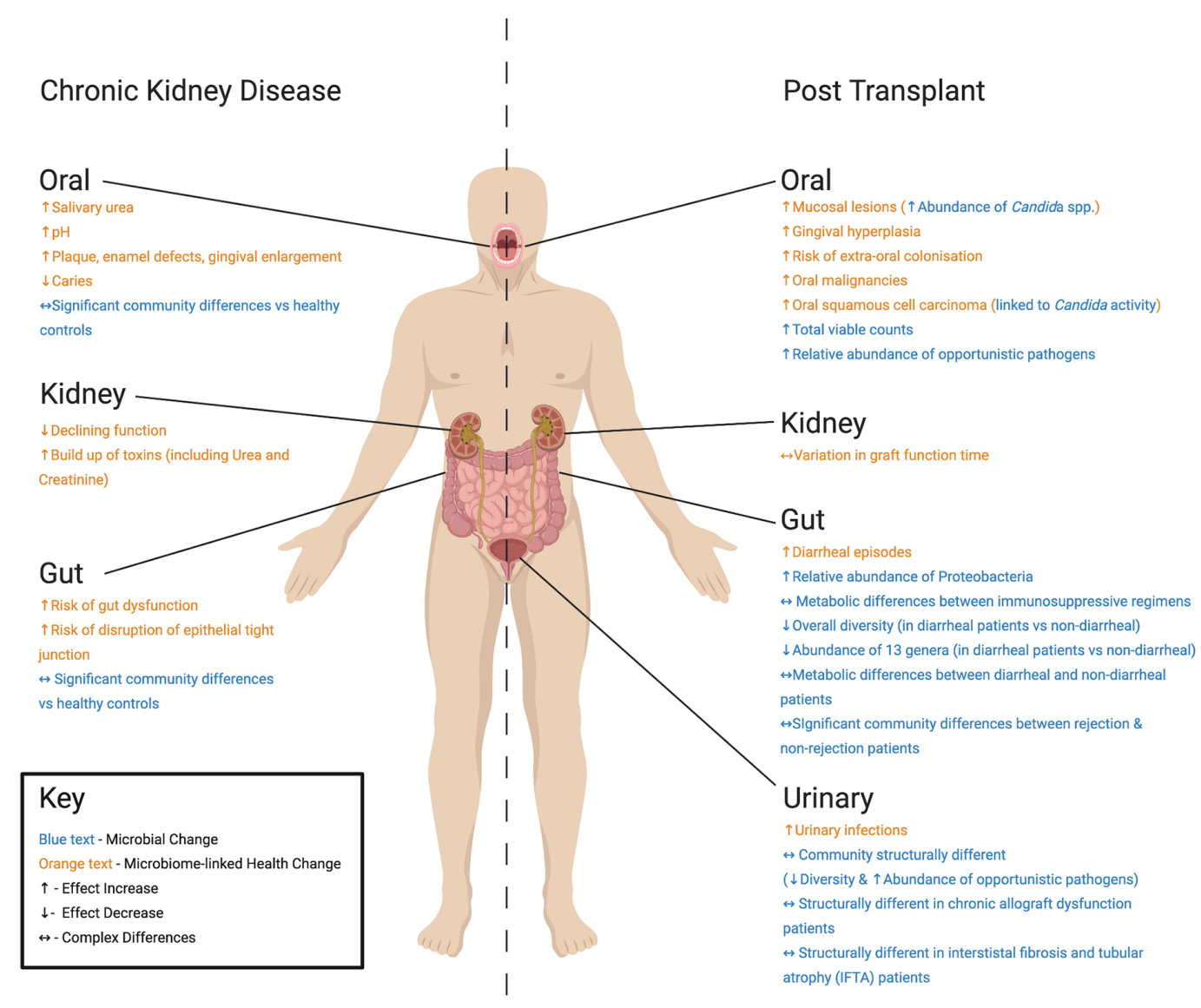

FIGURE 1 | Summary of differences found at key body sites in studies of Chronic Kidney Disease (CKD) patients and kidney transplant recipients post-operation discussed in this review. For CKD patients, health changes associated with microbiome alteration include: (Oral) increased urea and pH (Lasisi et al., 2016), plaque, enamel defects, gingival enlargement and decreased caries (Al Nowaiser et al., 2003), (Kidney) declining function and build-up of toxins (Pandya et al., 2016), and (Gut) gut dysfunction and disruption of epithelial tight junction (Vaziri et al., 2013b). Reported microbial change includes significant changes in oral and gut communities compared with healthy controls (Hu et al., 2018; Hobby et al., 2019). For kidney transplant recipients, post-transplant health changes associated with microbiome alteration include: (Oral) increased mucosal lesions, gingival hyperplasia, risk of extra-oral colonization, and squamous cell carcinoma (Spolidorio et al., 2006), (Kidney) variations in time taken for graft to function (Yarlagadda et al., 2009; Willicombe et al., 2017), (Gut) increased diarrheal episodes (Lee et al., 2014), and (Urinary Tract) increases in urinary tract infections (Giessing, 2012). Microbial changes include: (Oral) increased abundance of Candida species (Spolidorio et al., 2006), total viable microorganism counts (Saraiva et al., 2006), and relative abundance of opportunistic pathogens (Diaz et al., 2013), (Gut) increased relative abundance of Proteobacteria (Lee et al., 2014), changes in microbial metabolism between (i) immunosuppressive regimens (Zaza et al., 2017), as well as microbial community structure in (ii) rejection and non-rejection patients (Lee et al., 2014) and (iii) diarrheal and non-diarrheal patients (Lee et al., 2019). (Urinary Tract) Structurally different microbiomes are also seen in transplant recipients (Fricke et al., 2014), as well as chronic allograft dysfunction (Wu et al., 2018) and interstistal fibrosis and tubular atrophy patients (Modena et al., 2017).

and antibiotic administration. Translating these effects to animal models and in vitro systems, their relative impacts and interactions with microbial communities could then be isolated, understood, and, where required, interventions may be developed to alleviate co-morbidity, rejection and infection.

\section{AUTHOR CONTRIBUTIONS}

All authors ideated the review. PMC wrote the manuscript. All authors contributed to the article and approved the submitted version.

\section{FUNDING}

This review was written as part of a $\mathrm{PhD}$ studentship (Project Reference: 2102580) funded by the Medical Research Council.

\section{ACKNOWLEDGMENTS}

The authors would like to thank Houda Chea, the staff of the Renal Research Team at Manchester University NHS Foundation Trust, and the School of Pharmacy, University of Manchester. The figure for this paper was created with BioRender.com. 


\section{REFERENCES}

Ahn, S. Y., and Ingulli, E. (2008). Acute poststreptococcal glomerulonephritis: an update. Curr. Opin. Pediatr. 20, 157-162. doi: 10.1097/MOP.0b013e3282f45bcf

Al Khodor, S., and Shatat, I. F. (2017). Gut microbiome and kidney disease: a bidirectional relationship. Pediatr. Nephrol. 32, 921-931. doi: 10.1007/s00467016-3392-7

Al Nowaiser, A., Roberts, G., Trompeter, R., Wilson, M., and Lucas, V. (2003). Oral health in children with chronic renal failure. Pediatr. Nephrol. 18, 39-45. doi: 10.1007/s00467-002-0999-7

Andrade, M. R. T. C., Antunes, L. A. A., Soares, R. M. D. A., Leão, A. T. T., Maia, L. C., and Primo, L. G. (2013). Lower dental caries prevalence associated to chronic kidney disease: a systematic review. Pediatr. Nephrol. 29, 771-778. doi: 10.1007/ s00467-013-2437-4

Andrade-Oliveira, V., Amano, M. T., Correa-Costa, M., Castoldi, A., Felizardo, R. J., De Almeida, D. C., et al. (2015). Gut Bacteria Products Prevent AKI Induced by Ischemia-Reperfusion. J. Am. Soc. Nephrol. 26, 1877-1888. doi: 10.1681/ASN.2014030288

Aragon, I. M., Herrera-Imbroda, B., Queipo-Ortuno, M.II, Castillo, E., Del Moral, J. S., Gomez-Millan, J., et al. (2018). The Urinary Tract Microbiome in Health and Disease. Eur. Urol Focus 4, 128-138. doi: 10.1016/j.euf.2016.11.001

Ardalan, M., and Vahed, S. Z. (2017). Gut microbiota and renal transplant outcome. Biomed Pharmacother 90, 229-236. doi: 10.1016/j.biopha.2017.02.114

Bäumler, A. J., and Sperandio, V. (2016). Interactions between the microbiota and pathogenic bacteria in the gut. Nature 535, 85. doi: 10.1038/nature18849

Belkaid, Y., and Hand, T. W. (2014). Role of the microbiota in immunity and inflammation. Cell 157, 121-141. doi: 10.1016/j.cell.2014.03.011

Bergmann, O. J. (1989). Oral infections and fever in immunocompromised patients with haematologic malignancies. Eur. J. Clin. Microbiol. Infect. Dis. 8, 207-213. doi: 10.1007/bf01965262

Bliven, K., Snow, K., Carlson, A., Yeager, S., Kenyon, N., Smith, L., et al. (2018). Evaluating a Change in Surgical Antibiotic Prophylaxis in Kidney Transplant Recipients. Cureus 10, 1-11. doi: 10.7759/cureus.3433

Bowden, G., and Hamilton, I. (1987). Environmental pH as a factor in the competition between strains of the oral streptococci Streptococcus mutans, $S$. sanguis, and "S. mitior" growing in continuous culture. Can. J. Microbiol. 33, 824-827. doi: $10.1139 / \mathrm{m} 87-143$

Brown, R. S., Beaver, W. T., and Bottomley, W. K. (1991). On the mechanism of drug-induced gingival hyperplasia. J. Oral. Pathol. Med. 20, 201-209. doi: 10.1111/j.1600-0714.1991.tb00419.x

Buchfink, B., Xie, C., and Huson, D. H. (2015). Fast and sensitive protein alignment using DIAMOND. Nat. Methods 12, 59. doi: 10.1038/nmeth.3176

Bunnapradist, S., Lentine, K. L., Burroughs, T. E., Pinsky, B. W., Hardinger, K. L., Brennan, D. C., et al. (2006). Mycophenolate Mofetil Dose Reductions and Discontinuations after Gastrointestinal Complications Are Associated with Renal Transplant Graft Failure. Transplantation 82, 102-107. doi: 10.1097/ 01.tp.0000225760.09969.1f

Burne, R. A., and Marquis, R. E. (2000). Alkali production by oral bacteria and protection against dental caries. FEMS Microbiol Lett. 193, 1-6. doi: 10.1111/ j.1574-6968.2000.tb09393.x

Campistol, J. M., and Schena, F. P. (2007). Kaposi's sarcoma in renal transplant recipients-the impact of proliferation signal inhibitors. Nephrol. Dial. Transplant. 22, i17-i22. doi: 10.1093/ndt/gfm089

Casiano-Colón, A., and Marquis, R. E. (1988). Role of the arginine deiminase system in protecting oral bacteria and an enzymatic basis for acid tolerance. Appl. Environ. Microbiol. 54, 1318-1324. doi: 10.1128/aem.54.6.1318-1324.1988

Castellarin, M., Warren, R. L., Freeman, J. D., Dreolini, L., Krzywinski, M., Strauss, J., et al. (2012). Fusobacterium nucleatum infection is prevalent in human colorectal carcinoma. Genome Res. 22, 299-306. doi: 10.1101/gr.126516.111

Chen, Y. Y., Clancy, K. A., and Burne, R. A. (1996). Streptococcus salivarius urease: genetic and biochemical characterization and expression in a dental plaque streptococcus. Infect. Immun. 64, 585-592. doi: 10.1128/IAI.64.2.585-592.1996

Chiba, T., Marusawa, H., Seno, H., and Watanabe, N. (2008). Mechanism for gastric cancer development by Helicobacter pylori infection. J. Gastroenterol. Hepatol 23, 1175-1181. doi: 10.1111/j.1440-1746.2008.05472.x

Cippà, P. E., Schiesser, M., Ekberg, H., Van Gelder, T., Mueller, N. J., Cao, C. A., et al. (2015). Risk stratification for rejection and infection after kidney transplantation. Clin. J. Am. Soc. Nephrol. 10, 2213-2220. doi: 10.2215/CJN.01790215
Colombo, D., and Ammirati, E. (2011). Cyclosporine in transplantation - a history of converging timelines. J. Biol. Regulators Homeostatic Agents 25, 493.

Cowan, J., Bennett, A., Fergusson, N., Mclean, C., Mallick, R., Cameron, D. W., et al. (2018). Incidence rate of post-kidney transplant infection: a retrospective cohort study examining infection rates at a large Canadian multicenter tertiary-care facility. Can. J. Kidney Health Dis. 5, 2054358118799692. doi: $10.1177 / 2054358118799692$

de la Rosa-García, E., Mondragón-Padilla, A., Irigoyen-Camacho, M. E., and Bustamante-Ramírez, M. A. (2005). Oral lesions in a group of kidney transplant patients. Med Oral Patol Oral. Y Cirugia Bucal 10, 196.

de Macario, E. C., and Macario, A. J. (2009). Methanogenic archaea in health and disease: a novel paradigm of microbial pathogenesis. Int. J. Med. Microbiol. 299, 99-108. doi: 10.1016/j.ijmm.2008.06.011

Dethlefsen, L., Mcfall-Ngai, M., and Relman, D. A. (2007). An ecological and evolutionary perspective on human-microbe mutualism and disease. Nature 449, 811-818. doi: $10.1038 /$ nature06245

Diaz, P.II, Hong, B.-Y., Frias-Lopez, J., Dupuy, A. K., Angeloni, M., Abusleme, L., et al. (2013). Transplantation-associated long-term immunosuppression promotes oral colonization by potentially opportunistic pathogens without impacting other members of the salivary bacteriome. Clin. Vaccine Immunol CVI 20, 00734-00712. doi: 10.1128/CVI.00734-12

Díaz, P., Valenzuela Valderrama, M., Bravo, J., and Quest, A. F. (2018). Helicobacter pylori and gastric cancer: adaptive cellular mechanisms involved in disease progression. Front. Microbiol. 9, 5. doi: 10.3389/fmicb.2018.00005

Docktor, M. J., Paster, B. J., Abramowicz, S., Ingram, J., Wang, Y. E., Correll, M., et al. (2012). Alterations in diversity of the oral microbiome in pediatric inflammatory bowel disease. Inflammation Bowel Dis. 18, 935-942. doi: 10.1002/ibd.21874

Erra Díaz, F., Dantas, E., and Geffner, J. (2018). Unravelling the Interplay between Extracellular Acidosis and Immune Cells. Mediators Inflamm. 2018, 1-11. doi: $10.1155 / 2018 / 1218297$

Fan, X., Alekseyenko, A. V., Wu, J., Peters, B. A., Jacobs, E. J., Gapstur, S. M., et al. (2018). Human oral microbiome and prospective risk for pancreatic cancer: a population-based nested case-control study. Gut 67, 120-127. doi: 10.1136/ gutjnl-2016-312580

Farrell, J. J., Zhang, L., Zhou, H., Chia, D., Elashoff, D., Akin, D., et al. (2012). Variations of oral microbiota are associated with pancreatic diseases including pancreatic cancer. Gut 61, 582-588. doi: 10.1136/gutjnl-2011-300784

Fouts, D. E., Pieper, R., Szpakowski, S., Pohl, H., Knoblach, S., Suh, M. J., et al. (2012). Integrated next-generation sequencing of $16 \mathrm{~S}$ rDNA and metaproteomics differentiate the healthy urine microbiome from asymptomatic bacteriuria in neuropathic bladder associated with spinal cord injury. J. Transl. Med. 10:174. doi: 10.1186/1479-5876-10-174

Fricke, W., Maddox, C., Song, Y., and Bromberg, J. (2014). Human microbiota characterization in the course of renal transplantation. Am. J. Transplant. 14, 416-427. doi: 10.1111/ajt.12588

Galili, D., Donitza, A., Garfunkel, A., and Sela, M. N. (1992). Gram-negative enteric bacteria in the oral cavity of leukemia patients. Oral. Surg Oral. Med Oral. Pathol. 74, 459-462. doi: 10.1016/0030-4220(92)90295-2

Gardner, R., Velez, M., Ode, D., Lee, J. W., and Correa, H. (2004). Gamma/delta Tcell lymphoma as a recurrent complication after transplantation. Leukemia Lymphoma 45, 2355-2359. doi: 10.1080/10428190412331283215

Giessing, M. (2012). Urinary tract infection in renal transplantation. Arab J. Urol. 10, 162-168. doi: 10.1016/j.aju.2012.01.005

Giral-Classe, M., Hourmant, M., Cantarovich, D., Dantal, J., Blancho, G., Daguin, P., et al. (1998). Delayed graft function of more than six days strongly decreases long-term survival of transplanted kidneys. Kidney Int. 54, 972-978. doi: 10.1046/ j.1523-1755.1998.00071.x

Goyal, M. S., Venkatesh, S., Milbrandt, J., Gordon, J.II, and Raichle, M. E. (2015). Feeding the brain and nurturing the mind: Linking nutrition and the gut microbiota to brain development. Proc. Natl. Acad. Sci. U. S. A. 112, 1410514112. doi: 10.1073/pnas.1511465112

Guo, Y., Crnkovic, C. M., Won, K.-J., Yang, X., Lee, J. R., Orjala, J., et al. (2019). Commensal gut bacteria convert the immunosuppressant tacrolimus to less potent metabolites. Drug Metab. Disposition 47, 194-202. doi: 10.1124/dmd.118.084772

Gutierrez-Dalmau, A., and Campistol, J. M. (2007). Immunosuppressive therapy and malignancy in organ transplant recipients. Drugs 67, 1167-1198. doi: 10.2165/00003495-200767080-00006 
Halloran, P. F. (2004). Immunosuppressive drugs for kidney transplantation. N Engl. J. Med. 351, 2715-2729. doi: 10.1056/NEJMra033540

Han, Y., and Wang, X. (2013). Mobile microbiome: oral bacteria in extra-oral infections and inflammation. J. Dental Res. 92, 485-491. doi: 10.1177/ 0022034513487559

Han, S., Chen, Y., Hu, J., and Ji, Z. (2014). Tongue images and tongue coating microbiome in patients with colorectal cancer. Microbial Pathogen 77, 1-6. doi: $10.1016 /$ j.micpath.2014.10.003

Healy, C. M., and Moran, G. P. (2019). The microbiome and oral cancer: more questions than answers. Oral. Oncol. 89, 30-33. doi: 10.1016/j.oraloncology. 2018.12.003

Hickey, N. A., Shalamanova, L., Whitehead, K. A., Dempsey-Hibbert, N., Van Der Gast, C., and Taylor, R. L. (2020). Exploring the putative interactions between chronic kidney disease and chronic periodontitis. Crit. Rev. Microbiol. 46, 6177. doi: 10.1080/1040841X.2020.1724872

Hlava, N., Niemann, C. U., Gropper, M. A., and Melcher, M. L. (2009). Analytic Reviews: Postoperative Infectious Complications of Abdominal Solid Organ Transplantation. J. Intens Care Med. 24, 3-17. doi: 10.1177/0885066608327127

Hobby, G. P., Karaduta, O., Dusio, G. F., Singh, M., Zybailov, B. L., and Arthur, J. M. (2019). Chronic kidney disease and the gut microbiome. Am. J. Physiol Renal Physiol. 316, F1211-F1217. doi: 10.1152/ajprenal.00298.2018

Honda, K., and Littman, D. R. (2016). The microbiota in adaptive immune homeostasis and disease. Nature 535, 75-84. doi: 10.1038/nature18848

Hooper, L. V., Littman, D. R., and Macpherson, A. J. (2012). Interactions between the microbiota and the immune system. Science 336, 1268-1273. doi: 10.1126/ science. 1223490

Hu, J., Han, S., Chen, Y., and Ji, Z. (2015). Variations of tongue coating microbiota in patients with gastric cancer. BioMed. Res. Int. 2015, 1-7. doi: 10.1155/2015/ 173729

Hu, J., Iragavarapu, S., Nadkarni, G. N., Huang, R., Erazo, M., Bao, X., et al. (2018). Location-Specific Oral Microbiome Possesses Features Associated With CKD. Kidney Int. Rep. 3, 193-204. doi: 10.1016/j.ekir.2017.08.018

Huttenhower, C., Gevers, D., Knight, R., Abubucker, S., Badger, J. H., Chinwalla, A. T., et al. (2012). Structure, function and diversity of the healthy human microbiome. Nature 486, 207. doi: 10.1038/nature 11234

Idris, A., Hasnain, S. Z., Huat, L. Z., and Koh, D. (2017). Human diseases, immunity and the oral microbiota-Insights gained from metagenomic studies. Oral. Sci. Int. 14, 27-32. doi: 10.1016/S1348-8643(16)30024-6

Jakobsson, H. E., Jernberg, C., Andersson, A. F., Sjölund-Karlsson, M., Jansson, J. K., and Engstrand, L. (2010). Short-term antibiotic treatment has differing long-term impacts on the human throat and gut microbiome. PLoS One 5, 112. doi: 10.1371/journal.pone.0009836

Jansen, M. P., Pulskens, W. P., Uil, M., Claessen, N., Nieuwenhuizen, G., Standaar, D., et al. (2018). Urinary mitochondrial deoxyribonucleic acid associates with delayed graft function following renal transplantation. Nephrol. Dialysis Transplant. 35, 1320-1327. doi: 10.1093/ndt/gfy372

Karuthu, S., and Blumberg, E. A. (2012). Common infections in kidney transplant recipients. Clin. J. Am. Soc. Nephrol. 7, 2058-2070. doi: 10.2215/CJN.04410512

King, G. N., Healy, C. M., Glover, M. T., Kwan, J. T., Williams, D. M., Leigh, I. M., et al. (1994). Prevalence and risk factors associated with leukoplakia, hairy leukoplakia, erythematous candidiasis, and gingival hyperplasia in renal transplant recipients. Oral. Surg Oral. Med Oral. Pathol. 78, 718-726. doi: 10.1016/0030-4220(94)90086-8

Kleinberg, I., Jenkins, G. N., Chatterjee, R., and Wijeyeweera, L. (1982). The antimony $\mathrm{pH}$ electrode and its role in the assessment and interpretation of dental plaque $\mathrm{pH}$. J. Dent. Res. 61, 1139-1147. doi: 10.1177/00220345820610100601

Korpela, K., Salonen, A., Virta, L. J., Kekkonen, R. A., Forslund, K., Bork, P., et al. (2016). Intestinal microbiome is related to lifetime antibiotic use in Finnish pre-school children. Nat. Commun. 7, 10410. doi: 10.1038/ncomms10410

Kostic, A. D., Gevers, D., Pedamallu, C. S., Michaud, M., Duke, F., Earl, A. M., et al. (2012). Genomic analysis identifies association of Fusobacterium with colorectal carcinoma. Genome Res. 22, 292-298. doi: 10.1101/gr.126573.111

Langille, M. G., Zaneveld, J., Caporaso, J. G., McDonald, D., Knights, D., Reyes, J. A., et al. Predictive functional profiling of microbial communities using 16S rRNA marker gene sequences. Nat Biotechnol. 31 (9), 814-821. doi: $10.1038 /$ nbt.2676

Lardner, A. (2001). The effects of extracellular $\mathrm{pH}$ on immune function. J. Leukoc Biol. 69, 522-530. doi: 10.1189/jlb.69.4.522
Lasisi, T. J., Raji, Y. R., and Salako, B. L. (2016). Salivary creatinine and urea analysis in patients with chronic kidney disease: a case control study. $B M C$ Nephrol. 17, 10. doi: 10.1186/s12882-016-0222-x

Lee, Y. K., and Mazmanian, S. K. (2010). Has the microbiota played a critical role in the evolution of the adaptive immune system? Science 330, 1768-1773. doi: 10.1126/science. 1195568

Lee, J. R., Muthukumar, T., Dadhania, D., Toussaint, N. C., Ling, L., Pamer, E., et al. (2014). Gut microbial community structure and complications following kidney transplantation: a pilot study. Transplantation 98, 697. doi: 10.1097/ TP.0000000000000370

Lee, J. R., Muthukumar, T., Dadhania, D., Taur, Y., Jenq, R. R., Toussaint, N. C., et al. (2015). Gut microbiota and tacrolimus dosing in kidney transplantation. PLoS One 10, e0122399. doi: 10.1371/journal.pone.0122399

Lee, J. R., Magruder, M., Zhang, L., Westblade, L. F., Satlin, M. J., Robertson, A., et al. (2019). Gut microbiota dysbiosis and diarrhea in kidney transplant recipients. Am. J. Transplant. 19, 488-500. doi: 10.1111/ajt.14974

Lepp, P. W., Brinig, M. M., Ouverney, C. C., Palm, K., Armitage, G. C., and Relman, D. A. (2004). Methanogenic Archaea and human periodontal disease. Proc. Natl. Acad. Sci. U. S. A. 101, 6176-6181. doi: 10.1073/pnas.0308766101

Listgarten, M. A. (1986). Pathogenesis of periodontitis. J. Clin. Periodontol 13, 418-430. doi: 10.1111/j.1600-051x.1986.tb01485.x

Lynch, D. P. (1994). Oral candidiasis. History, classification, and clinical presentation. Oral. Surg. Oral. Med. Oral. Pathol. 78, 189-193. doi: 10.1016/ 0030-4220(94)90146-5

Marsh, P. D., and Devine, D. A. (2011). How is the development of dental biofilms influenced by the host? J. Clin. Periodontol 38, 28-35. doi: 10.1111/j.1600051X.2010.01673.x

Matas, A. J., Smith, J. M., Skeans, M. A., Thompson, B., Gustafson, S. K., Schnitzler, M. A., et al. (2014). OPTN/SRTR 2012 Annual Data Report: kidney. Am. J. Transplant. 14(Suppl 1), 11-44. doi: 10.1111/ajt.12579

McDonald, D., Ackermann, G., Khailova, L., Baird, C., Heyland, D., Kozar, R., et al. (2016). Extreme dysbiosis of the microbiome in critical illness. mSphere 1, e00199-e00116. doi: 10.1128/mSphere.00199-16

Modena, B. D., Milam, R., Harrison, F., Cheeseman, J. A., Abecassis, M. M., Friedewald, J. J., et al. (2017). Changes in urinary microbiome populations correlate in kidney transplants with interstitial fibrosis and tubular atrophy documented in early surveillance biopsies. Am. J. Transplant. 17, 712-723. doi: $10.1111 /$ ajt.14038

Moinuddin, J. F., and Lee, H. W.-T. (1958). Effects of feeding diets containing sucrose, cellobiose or glucose on the dry weights of cleaned gastrointestinal organs in the rat. Am. J. Physiol Legacy Content 192, 417-420. doi: 10.1152/ ajplegacy.1958.192.2.417

Morou-Bermudez, E., and Burne, R. A. (1999). Genetic and physiologic characterization of urease of Actinomyces naeslundii. Infection Immun. 67, 504-512. doi: 10.1128/IAI.67.2.504-512.1999

Nallu, A., Sharma, S., Ramezani, A., Muralidharan, J., and Raj, D. (2017). Gut microbiome in chronic kidney disease: challenges and opportunities. Trans. Res. 179, 24-37. doi: 10.1016/j.trsl.2016.04.007

Nascimento, M., Gordan, V., Garvan, C., Browngardt, C., and Burne, R. (2009). Correlations of oral bacterial arginine and urea catabolism with caries experience. Oral. Microbiol. Immunol. 24, 89-95. doi: 10.1111/j.1399-302X.2008.00477.x

Neuman, H., Debelius, J. W., Knight, R., and Koren, O. (2015). Microbial endocrinology: the interplay between the microbiota and the endocrine system. FEMS Microbiol. Rev. 39, 509-521. doi: 10.1093/femsre/fuu010

Oh, P., Martinez, I., Sun, Y., Walter, J., Peterson, D., and Mercer, D. F. (2012). Characterization of the ileal microbiota in rejecting and nonrejecting recipients of small bowel transplants. Am. J. Transplant. 12, 753-762. doi: 10.1111/j.16006143.2011.03860.x

Olczak-Kowalczyk, D., Pawlowska, J., Garczewska, B., Smirska, E., Grenda, R., Syczewska, M., et al. (2010). Oral candidiasis in immunosuppressed children and young adults after liver or kidney transplantation. Pediatr. Dent. 32, 189194.

Orlando, G., Manzia, T. M., Sorge, R., Iaria, G., Angelico, R., Sforza, D., et al. (2015). One-shot versus multidose perioperative antibiotic prophylaxis after kidney transplantation: a randomized, controlled clinical trial. Surgery 157, 104-110. doi: 10.1016/j.surg.2014.06.007

Pandya, D., Nagrajappa, A. K., and Ravi, K. S. (2016). Assessment and Correlation of Urea and Creatinine Levels in Saliva and Serum of Patients with Chronic 
Kidney Disease, Diabetes and Hypertension- A Research Study. J. Clin. Diagn. Res. 10, ZC58-ZC62. doi: 10.7860/JCDR/2016/20294.8651

Paraskevas, S., Huizinga, J. D., and Loos, B. G. (2008). A systematic review and meta-analyses on C-reactive protein in relation to periodontitis. J. Clin. Periodontol 35, 277-290. doi: 10.1111/j.1600-051X.2007.01173.x

Pester, M., Schleper, C., and Wagner, M. (2011). The Thaumarchaeota: an emerging view of their phylogeny and ecophysiology. Curr. Opin. Microbiol. 14, 300-306. doi: 10.1016/j.mib.2011.04.007

Peterson, S., Woodhead, J., and Crall, J. (1985). Caries resistance in children with chronic renal failure: plaque $\mathrm{pH}$, salivary $\mathrm{pH}$, and salivary composition. Pediatr. Res. 19, 796. doi: 10.1203/00006450-198508000-00003

Probst, A. J., Auerbach, A. K., and Moissl-Eichinger, C. (2013). Archaea on human skin. PLoS One 8, e65388. doi: 10.1371/journal.pone.0065388

Pushalkar, S., Mane, S. P., Ji, X., Li, Y., Evans, C., Crasta, O. R., et al. (2011). Microbial diversity in saliva of oral squamous cell carcinoma. FEMS Immunol. Med. Microbiol 61, 269-277. doi: 10.1111/j.1574-695X.2010.00773.x

Quivey, J. R., Kuhnert, W. L., and Hahn, K. (2000). Adaptation of oral streptococci to low pH. Adv. Microbial Physiol. 42, 239-274. doi: 10.1016/S0065-2911(00) 42004-7

Rani, A., Ranjan, R., Mcgee, H. S., Andropolis, K. E., Panchal, D. V., Hajjiri, Z., et al. (2017). Urinary microbiome of kidney transplant patients reveals dysbiosis with potential for antibiotic resistance. Trans. Res. 181, 59-70. doi: $10.1016 /$ j.trsl.2016.08.008

Rateitschak-Plüss, E., Hefti, A., Lörtscher, R., and Thiel, G. (1983). Initial observation that cyclosporin-A induces gingival enlargement in man. J. Clin. Periodontol 10, 237-246. doi: 10.1111/j.1600-051X.1983.tb01272.x

Ratzke, C., and Gore, J. (2018). Modifying and reacting to the environmental pH can drive bacterial interactions. PLoS Biol. 16, e2004248. doi: 10.1371/ journal.pbio. 2004248

Regev, E., Zeltser, R., and Lustmann, J. (1992). Lip carcinoma in renal allograft recipient with long-term immunosuppressive therapy. Oral. Surg Oral. Med Oral. Pathol. 73, 412-414. doi: 10.1016/0030-4220(92)90316-I

Ren, Z., Jiang, J., Lu, H., Chen, X., He, Y., Zhang, H., et al. (2014). Intestinal microbial variation may predict early acute rejection after liver transplantation in rats. Transplantation 98, 844. doi: 10.1097/TP.0000000000000334

Saraiva, L., Lotufo, R. F., Pustiglioni, A. N., Silva, H. T.Jr., and Imbronito, A. V. (2006). Evaluation of subgingival bacterial plaque changes and effects on periodontal tissues in patients with renal transplants under immunosuppressive therapy. Oral. Surg. Oral. Med. Oral. Pathol. Oral. Radiol Endod. 101, 457-462. doi: 10.1016/j.tripleo.2005.08.004

Sekirov, I., Russell, S. L., Antunes, L. C. M., and Finlay, B. B. (2010). Gut microbiota in health and disease. Physiol. Rev. 90, 859-904. doi: 10.1152/physrev.00045.2009

Sender, R., Fuchs, S., and Milo, R. (2016). Revised estimates for the number of human and bacteria cells in the body. PLoS Biol. 14, e1002533. doi: 10.1371/ journal.pbio. 1002533

Seymour, R. A., Thomason, J. M., and Nolan, A. (1997). Oral lesions in organ transplant patients. J. Oral. Pathol. Med. 26, 297-304. doi: 10.1111/j.1600-0714.1997.tb00219.x

Sinha, A., Velangi, S., and Natarajan, S. (2004). Non-Hodgkin's lymphoma following treatment of atopic eczema with cyclosporin A. Acta Dermatovenereol Stockholm 84, 327-328. doi: 10.1080/00015550410025967

Spencer, C. M., Goa, K. L., and Gillis, J. C. (1997). Tacrolimus. Drugs 54, 925-975. doi: 10.2165/00003495-199754060-00009

Spolidorio, L. C., Spolidório, D. M. P., Massucato, E. M. S., Neppelenbroek, K., Campanha, N., and Sanches, M. (2006). Oral health in renal transplant recipients administered cyclosporin A or tacrolimus. Oral. Dis. 12, 309-314. doi: 10.1111/j.1601-0825.2005.01200.x

Swarte, J. C., Douwes, R. M., Hu, S., Vich Vila, A., Eisenga, M. F., Van Londen, M., et al. (2020). Characteristics and Dysbiosis of the Gut Microbiome in Renal Transplant Recipients. J. Clin. Med. 9:386. doi: 10.3390/jcm9020386

Thaiss, C. A., Zmora, N., Levy, M., and Elinav, E. (2016). The microbiome and innate immunity. Nature 535, 65. doi: 10.1038/nature18847

Thomas, D., Seddon, S., and Shepherd, J. (1993). Systemic immunosuppression and oral malignancy: a report of a case and review of the literature. Br. J. Oral. Maxillofacial Surg. 31, 391-393. doi: 10.1016/0266-4356(93)90197-5

Vaishnava, S., Yamamoto, M., Severson, K. M., Ruhn, K. A., Yu, X., Koren, O., et al. (2011). The antibacterial lectin RegIIIgamma promotes the spatial segregation of microbiota and host in the intestine. Science 334, 255-258. doi: $10.1126 /$ science. 1209791
Vaziri, N. D., Yuan, J., Rahimi, A., Ni, Z., Said, H., and Subramanian, V. S. (2012). Disintegration of colonic epithelial tight junction in uremia: a likely cause of CKD-associated inflammation. Nephrol. Dial Transplant. 27, 2686-2693. doi: $10.1093 /$ ndt/gfr624

Vaziri, N. D., Wong, J., Pahl, M., Piceno, Y. M., Yuan, J., Desantis, T. Z., et al. (2013a). Chronic kidney disease alters intestinal microbial flora. Kidney Int. 83, 308-315. doi: 10.1038/ki.2012.345

Vaziri, N. D., Yuan, J., and Norris, K. (2013b). Role of urea in intestinal barrier dysfunction and disruption of epithelial tight junction in chronic kidney disease. Am. J. Nephrol. 37, 1-6. doi: 10.1159/000345969

Wahid, A., Chaudhry, S., Ehsan, A., Butt, S., and Khan, A. A. (2013). Bidirectional relationship between chronic kidney disease \& periodontal disease. Pak. J. Med. Sci. 29, 211. doi: 10.12669/pjms.291.2926

Wang, Y., Xue, J., Zhou, X., You, M., Du, Q., Yang, X., et al. (2014). Oral microbiota distinguishes acute lymphoblastic leukemia pediatric hosts from healthy populations. PLoS One 9, e102116. doi: 10.1371/journal.pone.0102116

Wang, B., Yao, M., Lv, L., Ling, Z., and Li, L. (2017). The human microbiota in health and disease. Engineering 3, 71-82. doi: 10.1016/J.ENG.2017.01.008

Wijeyeweera, R., and Kleinberg, I. (1989). Arginolytic and ureolytic activities of pure cultures of human oral bacteria and their effects on the $\mathrm{pH}$ response of salivary sediment and dental plaque in vitro. Arch. Oral. Biol. 34, 43-53. doi: 10.1016/0003-9969(89)90045-9

Willicombe, M., Rizzello, A., Goodall, D., Papalois, V., Mclean, A. G., and Taube, D. (2017). Risk factors and outcomes of delayed graft function in renal transplant recipients receiving a steroid sparing immunosuppression protocol. World J. Transplant. 7, 34. doi: 10.5500/wjt.v7.i1.34

Wolfe, A. J., Toh, E., Shibata, N., Rong, R., Kenton, K., Fitzgerald, M., et al. (2012). Evidence of uncultivated bacteria in the adult female bladder. J. Clin. Microbiol 50, 1376-1383. doi: 10.1128/JCM.05852-11

Wu, Z.-W., Ling, Z.-X., Lu, H.-F., Zuo, J., Sheng, J.-F., Zheng, S.-S., et al. (2012). Changes of gut bacteria and immune parameters in liver transplant recipients. Hepatobiliary Pancreatic Dis. Int. 11, 40-50. doi: 10.1016/S1499-3872(11) 60124-0

Wu, J. F., Muthusamy, A., Al-Ghalith, G. A., Knights, D., Guo, B., Wu, B., et al. (2018). Urinary microbiome associated with chronic allograft dysfunction in kidney transplant recipients. Clin. Transplant. 32, e13436. doi: 10.1111/ ctr. 13436

Yaling, L., Tao, H., Jingyi, Z., and Xuedong, Z. (2006). Characterization of the Actinomyces naeslundii ureolysis and its role in bacterial aciduricity and capacity to modulate pH homeostasis. Microbiol Res. 161, 304-310. doi: 10.1016/j.micres.2005.11.002

Yarlagadda, S. G., Coca, S. G., Formica, R. N.Jr., Poggio, E. D., and Parikh, C. R. (2009). Association between delayed graft function and allograft and patient survival: a systematic review and meta-analysis. Nephrol. Dialysis Transplant. 24, 1039-1047. doi: 10.1093/ndt/gfn667

Yoon, J. H., Yook, J.II, Kim, H. J., Cha, I. H., Yang, W.II, and Kim, J. (2003). Solitary plasmacytoma of the mandible in a renal transplant recipient. Int. J. Oral. Maxillofac Surg. 32, 664-666. doi: 10.1054/ijom.2002.0416

Zaza, G., Dalla Gassa, A., Felis, G., Granata, S., Torriani, S., and Lupo, A. (2017). Impact of maintenance immunosuppressive therapy on the fecal microbiome of renal transplant recipients: Comparison between an everolimus-and a standard tacrolimus-based regimen. PLoS One 12, e0178228. doi: 10.1371/ journal.pone. 0178228

Zhang, Z., Liu, L., Tang, H., Jiao, W., Zeng, S., Xu, Y., et al. (2018). Immunosuppressive effect of the gut microbiome altered by high-dose tacrolimus in mice. Am. J. Transplant. 18, 1646-1656. doi: 10.1111/ajt.14661

Conflict of Interest: The authors declare that the research was conducted in the absence of any commercial or financial relationships that could be construed as a potential conflict of interest.

Copyright $\odot 2020$ Campbell, Humphreys, Summers, Konkel, Knight, Augustine and McBain. This is an open-access article distributed under the terms of the Creative Commons Attribution License (CC BY). The use, distribution or reproduction in other forums is permitted, provided the original author(s) and the copyright owner(s) are credited and that the original publication in this journal is cited, in accordance with accepted academic practice. No use, distribution or reproduction is permitted which does not comply with these terms. 